J. Amer. Soc. Hort. SCI. 116(5):818-822. 1991.

\title{
Chemical Composition of Turnip Roots Stored or Intermittently Grown at Low Temperature
}

\author{
V.I. Shattuck', Y. Kakuda', B.J. Shelp', and N. Kakuda ${ }^{2}$ \\ University of Guelph, Guelph, Ontario N1G 2W1, Canada \\ Additional index words. Brassica rapa, storage, carbohydrates, sugars, glucosinolates
}

\begin{abstract}
Field and greenhouse studies were conducted to investigate the effects of low temperature on the starch, sugar, ascorbic acid, and glucosinolate (GS) concentration in turnip [Brassica rapa ssp. rapifera (Metzg.) Sinsk] roots. Field-harvested roots were stored at $\mathrm{OC}$ for 2 and 4 weeks. In the greenhouse, plants were grown at 0 to $12 \mathrm{C}$ for parts of 11 days before harvest. Cold-stored roots decreased in both starch and total sugar concentration (sucrose, fructose, and glucose) when compared to freshly harvested roots. Greenhouse-grown plants subjected to low temperatures had roots with a similar starch content but with a higher concentration of total sugars than the control. In both experiments, the cold treatments induced a slight but significant increase in root sucrose concentration. The ascorbic acid concentration of roots was not affected by low temperature. In both the field and greenhouse studies, low temperature did not change the total concentration of the eight major GSs identified in peeled root "and peel tissues, but did alter the concentration of specific GSs.
\end{abstract}

Turnips are popularly believed to retain good eating quality when stored under optimal conditions $(0 \mathrm{C}, 95 \%$ relative humidity). However, preliminary investigations have indicated that long-term storage of large roots of certain turnip cultivars, such as 'White Lady', resulted in appreciable flavor change (V.I.S. and Y. K., unpublished data). This observation is not surprising since variation in storage potential commonly exists among cultivars of other horticultural crops (Lidster et al., 1988; Ministry of Agriculture, Fisheries and Food, 1979) and low-temperatureinduced quality changes involving carbohydrates and GSs have been shown to occur in various cruciferous crops (Bérard and Chong, 1984; Guffy and Hicks, 1984; Peirce, 1987; Suzuki and Cutcliffe, 1981).

In spite of the economic importance of turnip, no reports have focused on the influence of low temperature on root quality. Low temperatures, besides affecting the sensory characteristics of the root, might also change other compounds that could ultimately lead to poor acceptance by consumers. This study was undertaken to determine the influence of low temperature on the starch, sugar, ascorbic acid, and GSs of a) field-grown turnip roots subjected to short-term refrigerated storage, and $b$ ) roots of intact greenhouse-grown plants before harvest. The first experiment was conducted since large turnip roots (>350 g) are occasionally harvested, detopped, and stored for short periods before being marketed. Since we obtained conflicting reports from turnip growers whether low night temperatures before harvest influence the quality of turnip roots, the second experiment was initiated.

\section{Materials and Methods}

'Purple Top White Globe' turnip (Stokes Seeds, St. Catharines, Ontario), the most widely marketed turnip in North America, was used in the field-storage and in the greenhouse studies.

Field-storage study. The turnips were planted at the Horticulture Research Station, Cambridge, Ontario, on 9 June 1989

Received for publication 30 May 1990. We gratefully acknowledge E.W. Underhill for performing the LC plasma spray mass spectrometry analysis and Denise McLellan for valuable technical assistance with HPLC techniques. The cost of publishing this paper was defrayed in part by the payment of page charges. Under postal regulations, this paper therefore must be hereby marked advertisement solely to indicate this fact.

'Dept. of Horticultural Science.

${ }^{2}$ Dept. of Food Science. on Fox Sandy loam soil. The experiment was set up in a randomized complete-block design with three replications. Plants were grown according to the standard cultural practices of the region (Ontario Ministry of Agriculture and Food, 1989). The roots were harvested on 10 Aug., 59 days after sowing and 1.5 months before the initial frosts in the region. Twenty roots were randomly selected from each replication, then all these roots were combined. From the 60 roots, 24 of uniform size were selected and divided into three groups of eight roots each. The treatments consisted of evaluating roots at harvest and after 2 and 4 weeks of storage at $0 \mathrm{C}$ and $93 \%$ relative humidity.

Greenhouse study. Plants were started in the greenhouse in seedling trays, then transplanted after 3.5 weeks into 6-liter pots (one plant/pot) containing vermiculite. The plants were grown in the greenhouse from September to December at $25 \pm 3 \mathrm{C}$. High-pressure sodium vapor lamps yielding a light intensity of $250 \mu \mathrm{mol} \cdot \mathrm{m}^{-2} \cdot \mathrm{s}^{-1}$ at the top of the plants were used each day for $14 \mathrm{~h}$ to supplement natural lighting. Each plant was normally watered with 1.0 liter of a nutrient solution every second day, but during extremely sunny days, they were irrigated daily with the nutrient solution.

The plants were initially irrigated with a nutrient solution $(\mathrm{pH}$ 6.5) containing (in mg.liter-1) $\mathrm{Ca}, 100 ; \mathrm{K}, 234 ; \mathrm{Mg}, 49 ; \mathrm{N}$, $168\left(139\right.$ as $\mathrm{NO}_{3}^{-}$and 28 as $\left.\left.\mathrm{NH}_{4}^{+}\right]\right) ; \mathrm{P}, 31 ; \mathrm{S}, 96 ; \mathrm{Cl}, 0.2 ; \mathrm{B}$, $1.0 ; \mathrm{Mn}, 0.1 ; \mathrm{Zn}, 0,05 ; \mathrm{Cu}, 0.05 ; \mathrm{Mo}, 0.02$; Co, 0.01; and $\mathrm{Fe}, 1.1$ (as FeNa ethylenedinitro-tetracetate). When the root/ hypocotyl of plants was 2 to $3 \mathrm{~cm}$ in diameter, which corresponded to 42 days after sowing, the $\mathrm{N}, \mathrm{K}$, and $\mathrm{B}$ concentrations in the nutrient solution were reduced to $78\left(63\right.$ as NO$^{-}$and 15 as $\mathrm{NH}_{4}^{+}$), 116, and $0.5 \mathrm{mg} \cdot$ liter ${ }^{-1}$ respectively.

Sixty-three days after sowing, the plants were divided into three treatments of uniformly sized roots consisting of six plants per treatment. The experiment consisted of a completely randomized design with each plant comprising a replication. In treatment $1\left(T_{1}\right)$, the plants were immediately harvested. For treatment $2\left(\mathrm{~T}_{2}\right)$, the plants were kept in the greenhouse under the conditions previously described, then harvested at the same time as $\mathrm{T}_{3}$. In treatment $3\left(\mathrm{~T}_{3}\right)$, the plants were subjected to a series of cold treatments for 11 days, then harvested. The plants were kept in the greenhouse during the daytime under the conditions previously described; during the night, they were ex-

Abbreviations: GS, glucosinolate; HPLC, high-performance liquid chromatography. 
posed in a refrigerated room to a sequence of two nights at 12 $\pm 1 \mathrm{C}$, three nights at $4 \pm 1 \mathrm{C}$, and six nights at $0 \pm 1 \mathrm{C}$. This temperature was used to acclimate plants to low temperature.

Ascorbic acid determination. Harvested roots were peeled, and a representative sample of midcore tissue was pulverized in a food processor with $6 \%$ metaphosphoric acid and $0.005 \mathrm{M}$ EDTA. The juice extract was filtered through glass wool and an aliquot was assayed for ascrobic acid content using the 2,6 dichlorophenolindo-phenol visual titration method (Assn. of Vitamin Chemists, 1966). Duplicate samples were analyzed and the data were averaged to give the values reported.

Sample preparation for remaining chemical analyses. Peeled roots were cut into pieces, and random samples were collected, quickly frozen in liquid $\mathrm{N}$, and stored at - 20C for not longer than 2 weeks. For the greenhouse study, the outer peel was also saved and frozen for GS evaluation. The frozen samples were subjected to freeze-drying, then sealed under vacuum in plastic bags, and stored at 5 to $6 \mathrm{C}$ until the chemical analyses were conducted. Tissues were macerated by use of an electric coffee grinder before being sampled.

Starch determination. A 1-g sample of freeze-dried material was refluxed in $100 \mathrm{ml}$ of $80 \%$ ethanol for $5 \mathrm{~h}$. The aqueous fraction was filtered and retained for sugars, the ethanol-insoluble residue was dried in an oven at $80 \mathrm{C}$ for $3 \mathrm{~h}$, and the starch in the residue was solubilized and hydrolyzed (Taylor et al., 1988). The liberated glucose was evaluated by an anthrone assay (Yem and Willis, 1954).

Soluble sugar determination. The filtered ethanol fraction from the 5-h reflux was rotoevaporated to near dryness and redissolved in $100 \mathrm{ml}$ of water. An aliquot of the resulting solution was filtered through an alumina Sep-Pak cartridge (Millipore Waters, Mississauga, Ontario) and a 0.45- $\mu$ M nylon membrane 66 filter. The solution was analyzed by high-performance liquid chromatography (HPLC) using a SP 8000 B Liquid Chromatography (Spectra Physics, Santa Clara, Calif.) fitted with an Aminex Carbohydrate HPX 87C column (300 x 7.8 mm) (BioRad, Richmond, Calif.). The column temperature was $85 \mathrm{C}$, and the mobile phase was water at a flow rate of $0.60 \mathrm{ml} \cdot \mathrm{min}^{-1}$. Sucrose, fructose, and glucose were quantified using peak height.

GS determination. GSs were extracted from $100 \mathrm{mg}$ of ground tissue using $5 \mathrm{ml}$ of boiling HPLC-grade methanol maintained in a water bath at $60 \mathrm{C}$ for $10 \mathrm{~min}$. A known quantity of benzylGS was added to each sample during the extraction as an internal standard. The tissue was re-extracted and combined extracts were evaporated to dryness at $4 \mathrm{C}$ on a Speed Vac Concentrator (Model SVC200H-115; Savant Instruments, Hicksville, N.Y.). The residue was defatted by redissolving in $1 \mathrm{ml}$ of hexane then $1 \mathrm{ml}$ of water; the solution was vortexed, centrifuged, and the upper hexane layer discarded. Fifty microliters of a $0.5-\mathrm{M}$ lead and barium acetate solution was added to the lower layer containing the water-soluble GSS to remove proteins. The solution was vortexed, then centrifuged. The supernatant was loaded onto prepared ion-exchange minicolumns and the GS desulfated using procedures previously described (Daun and McGregor, 1981; Sang et al., 1984). The desulfoglucosinolate solution was filtered through an aqueous $0.45-\mu$ ACRO LC3A filter, then analyzed by gradient system HPLC (Waters Assoc., Milford, Mass.). The HPLC system consisted of a model 481 gradient programmer and model 45 pumps. Separation was performed using a $\mathrm{C} 18(5 \mu \mathrm{m})$ reverse-phase column $(25 \mathrm{~cm} \mathrm{x} 4.6 \mathrm{~mm})$ (Alltech, Avondale, Pa.) with a linear gradient (0\% to $30 \%)$ acetonitrile/ $\mathrm{H}_{2} 0$ over $70 \mathrm{~min}$ at a flow rate of $1 \mathrm{ml} \cdot \mathrm{min}^{-1}$. Values of the various GSS were adjusted according to their re- sponse factors (Buchner, 1987). The identity of individual GSS was further confirmed using LC plasma spray mass spectrometry.

Statistical treatment. Analyses of variance were performed on the data and means were separated using Dunnett's test (Steel and Torrie, 1980) and Duncan's multiple range test.

\section{Results}

Field-grown roots had a mean fresh weight of $495 \pm 119 \mathrm{~g}$. No significant change in dry matter concentration occurred during storage (range $6.3 \%$ to $6.5 \%$ ), and no root growth or sprouting was visually apparent. Roots harvested from greenhousegrown plants had mean fresh weights for $\mathrm{T}_{1}, \mathrm{~T}_{2}$, and $\mathrm{T}_{3}$ of 349 $\pm 34 \mathrm{~g}, 495 \pm 37 \mathrm{~g}$, and $435 \pm 25 \mathrm{~g}$, respectively; dry weight was similar for all three groups $(6.2 \%$ to $7.0 \%)$. In both studies, harvested roots were free from brown heart (Shattuck and Shelp, 1985) and other types of internal discoloration. Mineral analyses revealed that the $\mathrm{N}, \mathrm{P}, \mathrm{K}, \mathrm{Ca}, \mathrm{Mg}, \mathrm{Mn}$, and $\mathrm{B}$ concentrations in roots of field and greenhouse-grown plants were similar; the $\mathrm{Cu}$ and $\mathrm{Zn}$ concentrations were lower in roots from greenhouse than field-grown plants.

During storage, the starch content of cold-stored roots from field-grown plants decreased $17 \%$ during the first 2 weeks then leveled off (Table 1). The starch content of greenhouse-grown roots was $22 \%$ lower for $\mathrm{T}_{2}$ than for $\mathrm{T}_{1}$, and no significant change was detected between treatments $T_{2}$ and $T_{3}$.

The major root sugars in turnips were glucose, fructose, and sucrose, with glucose and fructose accounting for $>90 \%$ of the total identified sugars. Several other neutral compounds were also detected, and although they were assumed to be sugars, they were in trace amounts and not identified. The total sugar concentration in roots was higher in field-grown plants at harvest than in greenhouse-grown $\mathrm{T}_{2}$ plants (Table 1).

In the field study, the glucose and fructose concentrations decreased proportionally during storage, as indicated by the constant glucose and fructose ratios at 2 and 4 weeks (Table 1). The sucrose concentration increased significantly during the first 2 weeks of storage and remained at a similar concentration thereafter. The total sugar content in roots was highest at harvest and decreased during the 4 weeks of storage (Table 1).

In the greenhouse-grown roots, fructose was the only sugar that increased in concentration between harvest $\mathrm{T}_{1}$ and $\mathrm{T}_{2}$ (Table 1). The low-temperature treatment caused an increase in sucrose, which resulted in an increase in total root sugars. The total sugar concentration was higher in $\mathrm{T}_{2}$ than $\mathrm{T}_{1}$, which was due to an increase in fructose (Table 1).

The overall means for ascorbic acid content of roots from field and greenhouse plants were $23.4 \pm 0.7$ and $24.8 \pm 0.5$ $\mathrm{mg} / 100 \mathrm{~g}$ fresh tissue, respectively (data not shown). Storage at 0C did not influence the ascorbic acid content of roots.

The most prevalent GS at harvest was 2-hydroxy-3-butenylGS, but 4-pentenyl-GS, 3-hydroxy-4-pentenyl-GS, and 2-phenylethyl-GS were also present at high concentrations (Table 2). These four GSs comprised $86 \%$ of the total detected. Cold storage for 4 weeks increased 2-hydro-3-butenyl-GS 34\% over freshly harvested roots, while 4-pentenyl-GS reached a maximum amount at 2 weeks before declining at 4 weeks to a concentration similar to that at harvest. During the 4 weeks of coldstorage, the total GS level did not change significantly (Table 2).

The principal GSs in peeled root tissues of greenhouse-grown $\mathrm{T}_{1}$ plants were 2-hydroxy-3-butenyl-GS and 4-pentenyl-GS (Table 3). Growth in the greenhouse for 11 days $\left(T_{1} v s . T_{2}\right)$ resulted 
Table 1. Starch and sugar concentrations and sugar ratios of peeled root tissue from field- and greenhouse-grown turnips.

\begin{tabular}{|c|c|c|c|c|c|c|c|}
\hline \multirow[b]{2}{*}{ Conditions } & \multicolumn{5}{|c|}{ Sugars (\% dry wt) } & \multirow{2}{*}{$\begin{array}{c}\text { Glucose : } \\
\text { fructose } \\
\text { ratio } \\
\end{array}$} & \multirow{2}{*}{$\begin{array}{c}\text { Sucrose : } \\
\text { glucose }+ \\
\text { fructose ratio }\end{array}$} \\
\hline & Starch & Glucose & Fructose & Sucrose & Total $^{2}$ & & \\
\hline \multicolumn{8}{|c|}{$\begin{array}{l}\text { Field-grown (weeks } \\
\text { in storage at } 0 \mathrm{C})^{y}\end{array}$} \\
\hline 0 & $2.39 \mathrm{a}$ & $27.7 \mathrm{a}$ & $20.4 \mathrm{a}$ & $3.6 \mathrm{a}$ & $51.7 \mathrm{a}$ & $1.36 \mathrm{a}$ & $0.07 \mathrm{a}$ \\
\hline 2 & $1.99 \mathrm{~b}$ & $25.3 \mathrm{a}$ & $19.1 \mathrm{a}$ & $4.6 \mathrm{~b}$ & $48.9 \mathrm{~b}$ & $1.32 \mathrm{a}$ & $0.11 \mathrm{~b}$ \\
\hline 4 & $2.08 \mathrm{~b}$ & $24.3 \mathrm{~b}$ & $17.6 \mathrm{~b}$ & $4.4 \mathrm{~b}$ & $46.3 \mathrm{~b}$ & $1.38 \mathrm{a}$ & $0.11 b$ \\
\hline \multicolumn{8}{|c|}{$\begin{array}{l}\text { Greenhouse-grown } \\
\quad \text { (growing conditions) }^{x}\end{array}$} \\
\hline$T_{1}$ & $2.50 \mathrm{a}$ & $24.8 \mathrm{a}$ & $14.2 \mathrm{a}$ & $2.5 \mathrm{a}$ & $41.4 \mathrm{a}$ & $1.75 \mathrm{a}$ & $0.06 \mathrm{a}$ \\
\hline $\mathrm{T}_{2}$ & $1.95 \mathrm{~b}$ & $24.6 \mathrm{a}$ & $17.0 \mathrm{~b}$ & $2.4 \mathrm{a}$ & $44.0 \mathrm{~b}$ & $1.45 \mathrm{ab}$ & $0.06 \mathrm{a}$ \\
\hline $\mathrm{T}_{3}$ & $1.70 \mathrm{~b}$ & $24.1 \mathrm{a}$ & $18.8 \mathrm{~b}$ & $3.2 \mathrm{~b}$ & $46.1 \mathrm{c}$ & $1.28 \mathrm{~b}$ & $0.07 \mathrm{a}$ \\
\hline
\end{tabular}

${ }^{2}$ Summation of sucrose, glucose, and fructose.

'Different letters in columns indicate significant difference from $\mathrm{O}$ weeks at $\mathrm{P} \leq 0.05$ by Dunnett's test.

${ }^{\mathrm{x}} \mathrm{T}_{1}$ plants harvested before the start of the cold treatments; $\mathrm{T}_{2}$ plants remained in the greenhouse and were not exposed to cold treatments; $\mathrm{T}_{3}$ plants subjected to 11 days of cold treatments (see text for details). Mean separation by Duncan's multiple range test at $\mathrm{P}<0.05$.

Table 2. Glucosinolate concentration ${ }^{2}$ of field-grown turnip roots without peel.

\begin{tabular}{lccc}
\hline \hline & \multicolumn{4}{c}{ Weeks in cold storage } \\
\cline { 2 - 4 } Shucosinolate $^{z}$ & 0 & 2 & 4 \\
\hline & $4.48 \mathrm{a}$ & $5.20 \mathrm{a}$ & $6.00 \mathrm{~b}$ \\
2-hydroxy-3-butenyl & $1.92 \mathrm{a}$ & $1.96 \mathrm{a}$ & $1.94 \mathrm{a}$ \\
3-hydroxy-4-pentenyl & $0.57 \mathrm{a}$ & $0.67 \mathrm{a}$ & $0.73 \mathrm{a}$ \\
5-methylsulfinylpentyl & $0.35 \mathrm{a}$ & $0.49 \mathrm{a}$ & $0.36 \mathrm{a}$ \\
3-butenyl & $0.36 \mathrm{a}$ & $0.42 \mathrm{a}$ & $0.40 \mathrm{a}$ \\
4-hydroxy-3-indolylmethy1 & $2.92 \mathrm{a}$ & $3.33 \mathrm{~b}$ & $2.51 \mathrm{a}$ \\
4-pentenyl & $1.93 \mathrm{a}$ & $2.17 \mathrm{a}$ & $1.80 \mathrm{a}$ \\
2-phenylethyl & $0.48 \mathrm{a}$ & $0.54 \mathrm{a}$ & $0.45 \mathrm{a}$ \\
1-methoxy-3-indolylmethyl & $13.01 \mathrm{a}$ & $14.78 \mathrm{a}$ & $14.19 \mathrm{a}$ \\
Total GS &
\end{tabular}

${ }^{2}$ Other GSs in trace amounts and not listed include 3-indolylmethyl, 4methoxy-3-indolylmethyl, and an unidentified saturated butyl-GS.

'Different letters in rows indicate a significant difference from $\mathrm{O}$ weeks at $\mathrm{P} \pm 0.05$ by Dunnett's test.

${ }^{x}$ Total value from the summation of glucosinolates presented.

in significantly lower 2-hydroxy-3-butenyl-GS (by 45\%), 3-butenyl-GS (by 18\%), 4-pentenyl-GS (by 23\%), and total GS (by $29 \%$ ) concentrations (Table 3). Plants subjected to the cold treatments $\left(\mathrm{T}_{3}\right)$ had roots with higher 4-pentenyl-GS and 4-hydroxy-3-indolylmethyl-GS but lower 1-methoxy-3-indolylmethyl-GS and 2-phenylethyl-GS concentrations than $\mathrm{T}_{2}$ roots (Table 3). Low-temperature storage of roots did not alter the total GS concentration.

The predominant GSs in peel tissue $\left(\mathrm{T}_{1}\right)$ were 4-pentenyl-GS, 2-hydroxy-3-butenyl-GS, 3-butenyl-GS, and 1-methoxy-3-indolylmethyl-GS (Table 3). With the exception of 2-hydroxy-3butenyl-GS, 5-(methylsulfinyl) pentyl-GS, and 4-hydroxy-3-indolylmethyl-GS, all other GSs changed in concentration over the 11 days of greenhouse growth, resulting in a $68 \%$ increase in total GS in $\mathrm{T}_{2}$ relative to $\mathrm{T}_{1}$. The only GS change associated with the cold treatment was a $129 \%$ increase in 4-hydroxy-3indolylmethyl-GS. The low-temperature treatment $\left(\mathrm{T}_{3}\right)$ did not alter the total GS concentration in peel tissue relative to $T_{2}$ (Table 3).

\section{Discussion}

In our study, field-harvested roots, when stored at low temperature, showed a decline in total soluble sugars. One of the most notable changes in some, but not all root crops, is lowtemperature-induced accumulation of soluble carbohydrates (Rutherford, 1977; Rutherford and Weston, 1968), where complex carbohydrates are hydrolyzed enzymatically to sugars (Dixon and Ap Rees, 1980; Isherwood, 1973; Miller and Langhans, 1990). Our data are similar to those reported for carrots, where total sugars decrease rapidly to about half the initial value after 60 days of cold storage (Phan et al., 1973), but differs from that of mature rutabaga (Brassica napus ssp. rapifera) roots, which accumulate sugars during short-term cold storage (Suzuki and Cutcliffe, 1981). It is noteworthy that turnip appeared to respond differently than rutabaga in as much as the amphidiploid rutabaga evolved from a cross between turnip and Brassica oleracea (Shattuck and Proudfoot, 1990). We noted a 2.7-mmol increase in sucrose in turnip roots during the first 2 weeks of storage; this increase was accompanied by a $0.40-\mathrm{g}$ decline in starch. Since the hydrolysis of $0.40 \mathrm{~g}$ of starch would be expected to yield $2.4 \mathrm{mmol}$ of glucose, it is likely that fructose and glucose from endogenous pools were also involved in the increase in sucrose during storage. When plants were exposed to low temperature in the greenhouse, the sucrose concentration in roots increased slightly, but glucose, fructose, and the starch concentrations remained stable. Presumably, the increase in sucrose in roots following the cold treatment arose from the translocation of this sugar from foliage tissues. The greenhouse study allowed for the first time a controlled examination of the unproven assumption that large (> $400 \mathrm{~g}$ ) field-grown turnip roots increase in sugar content following a series of frosts. Our greenhouse data supports this contention.

During cold storage and the low-temperature treatment, we did not detect any significant change in ascorbic acid content of turnip roots. The ascorbic acid values reported in our studies are consistent with the concentration $(25 \mathrm{mg} / 100 \mathrm{~g}$ fresh weight) normally expected for turnip (Buss and Robertson, 1976).

Our HPLC evaluation of turnip root GSs was verified by LC plasma spray mass spectrometry analysis and revealed eight principal compounds (Tables 2 and 3). Fenwick et al. (1983a) list 18 GSs that have been detected in turnip and likely contribute to the distinctive flavor and odor of this vegetable. Of the major GSs presented in our study, 4-hydroxy-3-indolylmethylGS, 4-methoxy-3-indolylmethyl-GS, 1-methoxy-3-indolylmethyl-GS, and 3-hydroxy-4-pentenyl-GS have not been pre- 
Table 3. GS concentration ${ }^{z}$ of greenhouse-grown turnip roots without peel and of peel tissue.

\begin{tabular}{|c|c|c|c|c|c|c|}
\hline \multirow[b]{2}{*}{ Glucosinolate } & \multicolumn{3}{|c|}{ Root without peely } & \multicolumn{3}{|c|}{ Peely } \\
\hline & $\mathrm{T}_{1}$ & $\mathrm{~T}_{2}$ & $\mathrm{~T}_{3}$ & $T_{1}$ & $\mathrm{~T}_{2}$ & $\mathrm{~T}_{3}$ \\
\hline & & & umol. & $d r y w t^{x}$ & & \\
\hline 2-hydroxy-3-butenyl & $3.00 \mathrm{a}$ & $1.64 \mathrm{~b}$ & $1.71 \mathrm{~b}$ & $1.70 \mathrm{a}$ & $1.94 \mathrm{ab}$ & $2.49 \mathrm{~b}$ \\
\hline 3-hydroxy-4-pentenyl & $0.80 \mathrm{a}$ & $0.49 \mathrm{a}$ & $0.56 \mathrm{a}$ & $0.41 \mathrm{a}$ & $0.86 \mathrm{~b}$ & $0.56 \mathrm{~b}$ \\
\hline 5-methylsulfinylpentyl & $0.26 \mathrm{a}$ & $0.18 \mathrm{a}$ & $0.22 \mathrm{a}$ & $0.21 \mathrm{a}$ & $0.33 \mathrm{ab}$ & $0.40 \mathrm{~b}$ \\
\hline 3-butenyl & $0.67 \mathrm{~b}$ & $0.55 \mathrm{a}$ & $0.72 \mathrm{~b}$ & $1.44 \mathrm{a}$ & $3.12 \mathrm{~b}$ & $3.14 \mathrm{~b}$ \\
\hline 4-hydroxy-3-indolylmethyl & $0.29 \mathrm{a}$ & $0.24 \mathrm{a}$ & $0.41 \mathrm{~b}$ & $0.74 \mathrm{a}$ & $0.80 \mathrm{a}$ & $1.83 \mathrm{~b}$ \\
\hline 4-pentenyl & $2.36 \mathrm{a}$ & $1.81 \mathrm{~b}$ & $2.37 \mathrm{a}$ & $2.24 \mathrm{a}$ & $4.46 \mathrm{~b}$ & $5.34 \mathrm{~b}$ \\
\hline 2-phenylethyl & $0.16 \mathrm{a}$ & $0.19 \mathrm{a}$ & $0.02 \mathrm{~b}$ & $0.67 \mathrm{a}$ & $0.14 \mathrm{~b}$ & $0.15 \mathrm{~b}$ \\
\hline 1-methoxy-3-indolylmethyl & $0.47 \mathrm{ab}$ & $0.57 \mathrm{a}$ & $0.40 \mathrm{~b}$ & $1.11 \mathrm{a}$ & $2.66 \mathrm{~b}$ & $2.37 \mathrm{~b}$ \\
\hline Total GS w & $8.01 \mathrm{a}$ & $5.67 \mathrm{~b}$ & $6.41 \mathrm{~b}$ & $8.52 \mathrm{a}$ & $14.31 \mathrm{~b}$ & $16.28 \mathrm{~b}$ \\
\hline
\end{tabular}

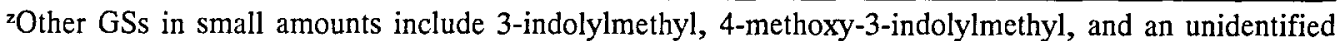
saturated butyl-GS.

${ } T_{1}$ plants harvested before the start of the cold treatments; $T_{2}$ plants remained in the greenhouse and were not exposed to cold treatments; $T_{3}$ plants subjected to 11 days of cold treatments (see text for details).

'Mean separation for the same GS among treatments of the same tissue by Duncan's multiple range test at $P \leq 0.05$.

wotal value from the summation of GSs presented.

viously reported in turnip. However, it should be noted that 4methoxy-3-indolylmethyl-GS and 1-methoxy-3-indolylmethyl-GS are known to occur in the hypocotyl (Sang et al., 1984) and mature root (Mossoba et al., 1989) of rutabaga. Since the indole-GSs are subject to degradation with gas-liquid chromatography separation, it is not surprising that earlier studies on turnip using GLC may not have detected the first three compounds. The values obtained in the field study for 3-butenyl-GS, 2hydroxy-3-butenyl-GS, and 4-pentenyl-GS (Table 2) agree well with a previous study involving field-grown 'Purple Top White Globe' peeled turnip (Carlson et al., 1981). However, striking concentration differences are noted for the other GSs when compared to the data of Carlson et al. (1981), which were obtained primarily through GLC analysis. Furthermore, we detected 4hydroxy-3-indolylmethyl-GS and 1-methoxy-3-indolymethyl-GS but not 1-methylpropyl-GS, 4-methylthiobutyl-GS, 2-hydroxy4-pentenyl-GS, and 5-methylthiopentyl-GS. These differences may have been due, in part, to the seed sources and the differences in analytical procedures (Sang et al., 1984) and in the growth environments (Freeman and Mossadeghi, 1972; MacLeod and Pikk, 1978).

During the 11-day interval between the harvests of $\mathrm{T}_{1}$ and $\mathrm{T}_{2}$ of greenhouse-grown plants, the roots increased in size from 349 to $495 \mathrm{~g}$ and significantly decreased in the mean GS content of the peeled root and increased in that of peel tissues (Table 3 ). The size of turnip roots has been shown to be inversely correlated with GS content of peeled roots in small $\mathrm{X}=400$ g), but no large $(\overline{\mathbf{X}}:>900 \mathrm{~g})$, roots (Carlson et al., 1981). This difference indicates that the GS content maybe subject to change during early sizing of the root, but this association is lost after roots reach a certain size. This finding may explain the marked changes we noted in GS. Since plants subjected to the cold treatment $\left(\mathrm{T}_{3}\right)$ yielded roots $12 \%$ smaller by weight than the control $\left(\mathrm{T}_{2}\right)$, comparisons involving the GSS between these treatments in our study should be approached with caution. For example, we recognize that it cannot be stated with certainty that the difference in 3-butenyl-GS between $T_{2}$ and $T_{3}$ roots resulted from the cold treatment and not from tissue dilution effects. However, it would appear that the cold treatment altered the concentrations of 4-hydroxy-3-indolylmethyl-GS in peeled roots and peel tissues and of 4-pentenyl-GS, 2-phenylethyl-GS, and 1-methoxy-3-indolylmethyl-GS in peeled roots (Table 3). Our study does not indicate whether the accumulation of the various GSs in peeled roots and peels following the cold treatment resulted from GS translocation from the foliage to roots, from GS biosynthesis in the root, or from a combination of both.

Although GS hydrolysis products have been widely used to quantify GS levels (Chong and Bérard, 1983; Ju et al., 1982b; Mullin and Sahasrabudhe, 1977), we decided in our study to measure the individual GSs present as the corresponding desulfoglucosinolates using HPLC. Data presented in Tables 2 and 3 suggest that storage at low temperature altered or induced the synthesis and degradation of specific GSs in turnip roots. This response was not associated with a change in the total concentration of the principal GSs measured. Several studies (Chong and Bérard, 1983; Guffy and Hicks, 1984) have revealed possible changes in GS levels during cold storage of cabbage by quantifying changes in aglucone products, but our experiment appears to be the first where individual GSs have been clearly identified to change in response to storage temperature. Our finding is in accordance to unpublished data by $\mathrm{Ju}$ (see Chong and Béard, 1983), who noted fluctuation in the hydrolysis products of GS in turnip cultivars during cold storage.

An interesting finding of our field study was that 2-hydroxy3-butenyl-GS (progoitrin) increased during short-term storage of turnip roots. Progoitrin is typically abundant in the turnip root (Chong et al., 1982; Mullin et al., 1980) and, following tissue disruption, is hydrolyzed to form 5-vinyl-oxazolidine-2thione, a potent goitrogen (Nishie and Daxenbichler, 1980; Van Etten, 1969), which is also linked to bitterness in tissues (Fenwick et al., 1983 b). A decrease in the reducing sugars (glucose and fructose) occurred during cold storage and was accompanied by an increase in progoitrin concentration (Tables 1 and 2). Although the biological significance of this relationship is unclear, it may reflect a general stress response of turnip roots. A similar relationship has been reported in B-deficient turnip (Ju et al., 1982a). In view of the concerns of today's health- and quality-conscious consumers, it would be useful to know whether the levels of progoitrin and sugars continue to change in turnip roots when stored beyond 4 weeks.

Our results suggest that low temperature affects both carbo- 
hydrate and glucosinolate metabolism in turnip roots and the effects are dependent on the low-temperature treatment. Further studies are required to ascertain if the alteration of carbohydrates and glucosinolates at low temperature could have affected the sensory characteristics of roots.

\section{Literature Cited}

Association of Vitamin Chemists. 1966. L-ascorbic acid (vitamin C), p. 287-341. In: M. Freed (cd.). Methods of vitamin assay. Interscience, New York.

Bérard, L. S. and C. Chong. 1984. Influence of storage on glucosinolate fluctuations in cabbage. Acta Hort. 157:203-209.

Buchner, R. 1987. Response factors, p. 50-58. In: J.P. Wathelet (cd.). Glucosinolates in rapeseed: Analytical aspects. Martinus Nijhoff, Boston.

Buss, D. and J. Robertson. 1976. Manual of nutrition. Ministry of Agr. Fisheries, \& Food Publ. 342. Her Majesty's Stationery Office, London.

Carlson, D. G., M.E. Daxenbichler, C.H. Van Etten, H.L. Tookey, and P.H. Williams. 1981. Glucosinolates in crucifer vegetables: Turnip and rutabaga. J. Agr. Food Chem. 29:1235-1239.

Chong, C. and L.S. Bérard. 1983. Changes in glucosinolates during refrigerated storage of cabbage. J. Amer. Soc. Hort. Sci. 108:688691.

Chong, C., H.-Y. Ju, and B.B. Bible. 1982. Glucosinolate composition of turnip and rutabaga cultivars. Can. J. Plant Sci. 62:533-536.

Daun, J.K. and D.I. McGregor. 1981. Glucosinolate analysis of rapeseed (canola). Canadian Grain Commission Publ., Winnipeg, Canada.

Dixon, W.L. and T. Ap Rees. 1980. Carbohydrate metabolism during cold-induced sweetening of potato tubers. Photochemistry 19:16531656.

Fenwick, G. R., R.K. Heaney, and W.J. Mullins. 1983a. Glucosinolates and their breakdown products in food and food plants. Chem. Rubber Co. Critical Rev. Food Sci. Nutr. 18:123-201.

Fenwick, G. R., N.M. Griffiths, and R.K. Heaney. 1983b. Bitterness in brussels sprouts (Brassica oleracea L. var. gemmifera): The role of glucosinolates and their breakdown products. J. Sci. Food Agr. 34:73-80.

Freeman, G.G. and N. Mossadeghi. 1972. Influence of sulphate nutrition on flavour components of three cruciferous plants: Radish (Raphranus sativus), cabbage (Brussica oleracea capilata) and white mustard (Sinapis alba). J. Sci. Food Agr. 23:387-402.

Guffy, S.K. and J.R. Hicks. 1984. Effect of cultivar, maturity and storage on respiration, dry weight and glucosinolate content of cabbage. Acta Hort. 157:211-218.

Isherwood, F.A. 1973. Starch-sugar interconversion in Solanum tuberosum. Photochemistry 12:2579-2591.

Ju, H.-Y., C. Chong, and B.B. Bible. 1982a. Influence of boron nutrition on glucosinolates and reducing sugars in turnip. Can. J. Plant Sci. 62:1037-1042.

Ju, H.-Y., C. Chong, W.J. Mullin, and B. Bible. 1982b. Volatile isothiocyanates and nitriles from glucosinolates in rutabaga and turnip. J. Amer. Soc. Hort. Sci. 107:1050-1054.

Lidster, P. D., P.D. Hildebrand, L.S. Berard, and S.W. Porritt. 1988.
Commercial storage of fruits and vegetable. Publ. 1532/E, Agriculture Canada.

MacLeod, A.J. and H.E. Pikk. 1978. A comparison of the chemical flavour composition of some brussels sprouts cultivars grown at different crop spacings. Photochemistry 17:1029-1032.

Miller, W.B. and R.W. Langhans. 1990. Low temperature alters carbohydrate metabolism in caster lily bulb. HortScience 25:463-465.

Ministry of Agriculture, Fisheries, and Food. 1979. Refrigerated storage of fruit and vegetables. Her Majesty's Stationery Office, London, England.

Mossoba, M.M., G.J. Shaw, D. Andrzeyewski, J.A. Sphon, and S.W. Page. 1989. Application of gas chromatography/matrix isolation/fourier transform infrared spectrometry to the identification of glucosinolates from Brassica vegetables. J. Agr. Food Chem. 37:367-372.

Mullin, W. J., K.G. Proudfoot, and M.J. Collins. 1980. Glucosinolate content and clubroot of rutabaga and turnip. Can. J. Plant Sci. 60:605612.

Mullin, W.J. and M.R. Sahasrabudhe. 1977. Glucosinolate content of cruciferous vegetable crops. Can. J. Plant Sci. 57:1227-1230.

Nishie, K. and M.E. Daxenbichler. 1980. Toxicology of glucosinolates, related compounds (nitriles, R-goitrin, isothiocyanates) and vitamin $\mathrm{U}$ found in cruciferae. Food Cosmetics Toxicol. 18:159172.

Ontario Ministry of Agriculture and Food. 1989. Vegetable production recommendations. Queen's Printer for Ontario, Canada.

Peirce, L.C. 1987. Vegetables, characteristics, production and marketing. Wiley, Toronto.

Phan, C. T., H. Hsu, and S.K. Sarkar. 1973. Physical and chemical changes occurring in the carrot root during storage. Can. J. Plant Sci. 53:635-641.

Rutherford, P.P. 1977. Carbohydrate changes in stored vegetables with special reference to red beet and parsnip. Ann. Applied Biol. 85:440444.

Rutherford, P.P. and E.W. Weston. 1968. Carbohydrate changes during cold storage of some inulin-containing roots and tubers. Photochemistry 7: 175-180.

Sang, J. P., I.R. Minchinton, P.K. Johnstone, and R.J.W. Truscott. 1984. Glucosinolate profiles in the seed, root and leaf tissue of cabbage, mustard, rapeseed, radish and swede. Can. J. Plant Sci. 64:77-93.

Shattuck, V.I. and K.G. Proudfoot. 1990. Rutabaga breeding. Plant Breeding Rev. 8:217-247.

Shattuck, V.I. and B.J. Shelp. 1985. Brown heart in rutabaga. Ontario Ministry Agr. Food Factsheet 85-104. Ontario Ministry of Agriculture and Food, Toronto, Canada.

Steel, R.G.D. and J.H. Torrie. 1980. Principles and procedures of statistics. McGraw-Hill, New York.

Suzuki, M. and J.A. Cutcliffe. 1981. Sugars and eating quality of rutabagas. Can. J. Plant Sci. 61:167-169.

Taylor, D. C., B.J. Shelp, L.M. Nelson, and B. Grodzinski. 1988. Carbon and nitrogen partitioning in young nodulated pea (wild type and nitrate reductase-deficient mutant) plants exposed to $\mathrm{NH}_{4} \mathrm{NO}_{3}$. Physiol. Plant. 74:593-601.

Van Etten, C.H. 1969. Goitrogens, p. 103-142. In: I.E. Liener (ed.). Toxic constituents of plant foodstuffs. Academic, New York.

Yem, E.E. and A.J. Willis. 1954. The estimation of carbohydrates in plant extracts by anthrone. Biochem. J. 57:508-514. 